\title{
PENGARUH KEPUASAN KERJA, KEPERCAYAAN TERHADAP ORGANISASI (TRUST) DAN KETIDAKAMANAN KERJA (JOB INSECURITY) TERHADAP INTENSI KELUAR (TURNOVER INTENTION) PADA PT. ASIA PETROCOM SERVICES (APS) DURI
}

\author{
Irien Violinda Anggriani \\ Fakultas Ekonomi dan Sosial UIN Sultan Syarif Kasim Riau - Pekanbaru \\ E-mail: irienviolinda@uin-suska.id \\ Niko Hambari \\ Fakultas Ekonomi dan Sosial UIN Sultan Syarif Kasim Riau - Pekanbaru \\ E-mail: niko.hambari@uin-suska.id
}

\begin{abstract}
Abstrak
Penelitian ini bertujuan untuk mengetahui pengaruh Kepuasan Kerja, Kepercayaan Terhadap Organisasi (Trust) dan Ketidakamanan Kerja (Job Insecurity) terhadap Intensi Keluar (Turnover Intention) pada PT. Asia Petrocom Services (APS) Duri. Sampel dalam penelitian ini berjumlah 71 orang karyawan dengan menggunakan metode analisis regresi linier berganda baik simultan maupun parsial. Dapat disimpulkan bahwa secara parsial Kepuasan Kerja dan Kepercayaan Terhadap Organisasi (Trust) berpengaruh negatif signifikan terhadap Intensi Keluar (Turnover Intention) dan Ketidakamanan Kerja berpengaruh positif signifikan terhadap Intensi Keluar (Turnover Intention), Sedangkan secara simultan Kepuasan Kerja, Kepercayaan Terhadap Organisasi (Trust)dan Ketidakamanan Kerja (Job Insecurity) berpengaruh terhadap Intensi Keluar (Turnover Intention) pada PT. Asia Petrocom Services (APS) Duri. Dan Ketidakamanan Kerja (Job Insecurity) menjadi variabel yang dominan berpengaruh terhadap Intensi Keluar (Turnover Intention). Dapat diketahui faktor-faktor yang mempengaruhi turnover intention yaitu Kepuasan Kerja, Kepercayaan Terhadap Organisasi (Trust), dan Ketidakamanan Kerja (Job Insecurity). Dalam penelitian ini kepuasan kerja dan kepercayaan terhadap organisasi (Trust) berpengaruh negatif maksudnya adalah karyawan yang memiliki tingkat kepuasan dan kepercayaan yang tinggi secara pasti tidak akan memiliki pikiran atau niat untuk keluar dari organisasi (turnover intention).
\end{abstract}

Kata Kunci : Kepuasan Kerja, Kepercayaan Terhadap Organisasi (Trust), Ketidakamanan Kerja (Job Insecurity) dan Intensi Keluar (Turnover Intention)

\section{PENDAHULUAN}

Salah satu elemen penting dalam suatu organisasi adalah sumber daya manusia yang mampu menggerakkan seluruh aktivitas guna pencapaian tujuan pada organisasi tersebut. Sumber daya manusia merupakan salah satu bagian dalam perusahaan yang memiliki peran penting dalam menentukan 
pencapaian hasil dan merupakan modal atau aset bagi perusahaan. Namun masalah yang sering dihadapi adalah adanya faktor sikap dan prilaku karyawan yang tidak dapat dikendalikan dalam proses pengelolaan sumber daya manusia hingga berujung pada keinginan untuk keluar bahkan langsung keluar dari organisasi. Menurut Elsa Frischa Wijaya (2010) terdapat banyak faktor yang membuat individu memiliki keinginan untuk berpindah (turnover intention). Faktor-faktor tersebut diantaranya adalah kepuasan kerja, komitmen organisasi terhadap karyawan, kepercayaan terhadap organisasi (trust) dan job insecurity.

Hal ini juga sejalan dengan pendapat bebrapa para ahli tentang faktor yang mempengaruhi turnover intention diantaranya adalah Kepuasan Kerja Karyawan dengan kepuasan kerja akan merasa senang dan bahagia dalam melakukan pekerjaannya dan tidak berusaha mengevaluasi alternatif pekerjaan lain. Sebaliknya karyawan yang merasa tidak puas dalam pekerjaannya cenderungmempunyai pikiran untuk keluar, mengevaluasi alternatif pekerjaan lain, dan berkeinginan untuk keluar karena berharap menemukan pekerjaan yang lebih memuaskan Mobley (1997). Begitu pula dengan Penelitian yang dilakukan oleh Pasewark dan Strawser (1996) dalam Suwandi dan Indriartoro (1999) tentang Kepercayaan Terhadap Organisasi (Trust) menguji model turnover dengan menggunakan konstruk kepercayaan organisasional.

Studi yang dilakukan oleh Barling dan Kelloway dalam Probst (2001) menunjukkan adanya kaitan antara job insecurity dan turnover intention. Intensi keluar/niat pindah kerja (turnover intention) yang dapat berujung pada keputusan karyawan meninggalkan pekerjannya.

Faktor-faktor yang mempengaruhi tingkat intensi keluar (turnover intention) salah satunya adalah kepuasan kerja. Kepuasan kerja merupakan sifat individual dengan tingkat berbeda pada setiap karyawan. Kepuasan kerja juga berkaitan dengan kepercayaan terhadap organisasi (trust), menurut Robbins dan Judge (2008), kepercayaan adalah suatu eskpektasi dan pengharapan positif bahwa orang lain tidak akan melalui kata-kata, tindakan, dan kebijakan bertindak secara oportunistik. Kepercayaan merupakan suatu kondisi anggota organisasi memberikan kemampuan dan kesetiaan pada organisasi dalam mencapai tujuan. Dari teori di atas, maka dapat dikatakan bahwa antara kepuasan kerja, kepercayaan terhadap organisasi (trust) dan ketidakamanan kerja (job insecurity) mempunyai hubungan yang erat dengan intensi keluar (turnover intention).

Adapun subjek yang akan dijadikan sampel dalam penelitian ini adalah pada PT. Asia Petrocom Services (APS) Duri. Perusahaan ini merupakan salah satu perusahaan kontraktor yang bergerak pada bidang pengeboran minyak/drilling yang di dirikan pada tahun 2011. Sebagai perusahaan yang baru berdiri, PT. Asia Petrocom Services (APS) mendapatkan kontrak perdana dengan perusahaan Migas dunia yaitu PT. Chevron. Pada kontrak kerjasama pertama yang di terima, PT. Asia Petrocom Services (APS) 
menerima kontrak kerja untuk 1 Rig drilling selama 1 tahun pertama. Dalam perjanjian kontrak yang di berikan untuk tahun-tahun berikutnya, PT. Asia Petrocom Services (APS) melakukan perpanjangan kontrak pada setiap akhir tahun dan perpanjangan kontrak di tetapkan selama 1 tahun ke depan. Pada tahun 2013 PT. Asia Petrocom Services (APS) mendapatkan kontrak kerja sama dengan PT. Chevron untuk perawatan sumur atau service sumur dengan waktu kontrak kerja selama 4 tahun dengan jumlah Rig yang di berikan sebanyak 4 unit PT. Asia Petrocom Service (APS) siap untuk menjalankan 4 Rig yang sudah di berikan kepercyaan oleh PT. Chevron. Selanjutnya, PT. Asia Petrocom Services (APS) ini memiliki kendala yang berkaitan dengan jumlah karyawan untuk menjalankan 4 Rig tersebut. Dalam hal ini PT. Asia Petrocom Services (APS) mengambil tindakan untuk melakukan rekrut karyawan untuk

Tabel 1: Data Jumlah Karyawan dan Tingkat Labour Turnover (LTO) Karyawan PT. Asia Petrocom Services (APS) Duri.

\begin{tabular}{|c|c|c|c|c|c|c|}
\hline Tahun & $\begin{array}{c}\text { Jumlah } \\
\text { karyawan } \\
\text { awal } \\
\text { tahun }\end{array}$ & $\begin{array}{c}\text { Jumlah } \\
\text { karyawan } \\
\text { masuk }\end{array}$ & $\begin{array}{c}\text { Jumlah } \\
\text { karyawan } \\
\text { keluar }\end{array}$ & $\begin{array}{c}\text { Jumlah } \\
\text { karyawan } \\
\text { akhir tahun }\end{array}$ & $\begin{array}{c}\text { Jumlah } \\
\text { rata-rata } \\
\text { karyawan }\end{array}$ & $\begin{array}{c}\text { Tingkat } \\
\text { LTO } \\
(\%)\end{array}$ \\
\hline 2011 & 173 & 0 & 1 & 172 & 172,5 & $0,5 \%$ \\
\hline 2012 & 172 & 18 & 2 & 188 & 180 & $1,1 \%$ \\
\hline 2013 & 188 & 29 & 1 & 216 & 202 & $0,4 \%$ \\
\hline 2014 & 216 & 19 & 4 & 231 & 223,5 & $1,7 \%$ \\
\hline 2015 & 231 & 16 & 6 & 241 & 236 & $2,5 \%$ \\
\hline
\end{tabular}

\section{Sumber: Data Olahan PT. Asia Petrocom Services (APS) Duri, 2016}

Dari tabel 1 dapat dilihat bahwa jumlah keluar masuk karyawan mengalami fluktuasi. Pada tahun 2011 pada PT. Asia Petrocom Services (APS) menerima karyawan memenuhi kebutuhan. Kebutuhan akan jumlah karyawan untuk menjalankan 1 Rig adalah sebanyak \pm 42 orang karyawan.

Dengan jumlah Rig sebanyak 4 unit, maka PT. Asia Petrocom Services (APS) membutuhkan karyawan \pm 300 orang karyawan untuk menjalankan 4 Rig tersebut. Setelah beberapa kurun waktu di lewati, PT. Asia Petrocom Services (APS) akhirnya dapat memenuhi jumlah karyawan yang dibutuhkan dan menjalani kontrak dengan PT. Chevron dengan baik. Hingga saat ini PT. Asia Petrocom Services (APS) sudah berjalan selama 5 tahun dan jumlah karyawan pada saat ini 241 orang. Dari pertama berdiri hingga sekarang PT. Asia Petrocom Service (APS) memberikan yang terbaik untuk karyawan, namun pada sekarang ini terlihat penurunan tingkat kepuasan yang dapat dilihat dari tingkat turnover karyawan yang keluar masuk perusahaan seperti pada berikut ini:

sebanyak 173 orang dan karyawan yang keluar sebanyak 1 orang, sehingga terjadi tingkat Labour Turnover (LTO) sebesar 0,5\%. Pada tahun 2012 perusahaan menerima 
karyawan sebanyak 18 orang dan karyawan yang keluar sebanyak 2 orang, sehingga tingkat LTO mengalami kenaikan menjadi $1,1 \%$. Pada tahun 2013 perusahaan menerima karyawan sebanyak 29 orang dan karyawan yang keluar sebanyak 1 orang, sehingga tingkat LTO mengalami penurunan menjadi 0,4\%. Pada tahun 2014 perusahaan menerima karyawan sebanyak 19 orang dan karyawan yang keluar sebanyak sebanyak 4 orang, sehingga tingkat LTO mengalami kenaikan menjadi $1,7 \%$. Sedangkan pada tahun 2015 perusahaan menerima karyawan sebanyak 16 orang dan karyawan yang keluar sebanyak 6 orang, sehingga tingkat LTO meningkat tinggi menjadi $2,5 \%$.

Dari keterangan diatas, dapat kita ketahui bahwa tingkat LTO yang terjadi pada PT. Asia Petrocom Services (APS) Duri mengalami fluktuasi, sehingga dapat dikatakan keinginan keluar (turnover intention) karyawan menjadi nyata. ini menunjukkan bahwa terdapat penurunan kepuasan kerja karyawan yang belum banyak terpenuhi oleh perusahaan dan ketidakamanan kerja (job insecuriry) merupakan faktor pendukung LTO .

\section{Perumusan Masalah}

Dari latar belakang masalah yang telah diuraikan diatas dengan judul Pengaruh Kepuasan Kerja, Kepercayaan Terhadap Organisasi (Trust) dan Ketidakamanan Kerja (Job Insecurity) Terhadap Intensi Keluar (Turnover Intention) Pada PT. Asia Petrocom Services (APS) Duri, penulis merumuskan rumusan masalah dalam penelitian ini sebagai berikut:
1. Apakah Kepuasan Kerja secara parsial berpengaruh signifikan terhadap Intensi Keluar (Turnover Intention) pada PT. Asia Petrocom Services (APS) Duri?

2. Apakah Kepercayaan Terhadap Organisasi (Trust) secara parsial berpengaruh signifikan terhadap Intensi Keluar (Turnover Intention) pada PT. Asia Petrocom Services (APS) Duri?

3. Apakah Ketidakamanan Kerja (Job Insecurity) secara parsial berpengaruh signifikan terhadap Intensi Keluar (Turnover Intention) pada PT. Asia Petrocom Services (APS) Duri?

4. Apakah Kepuasan Kerja, Kepercayaan Terhadap Organisasi (Trust) dan Ketidakamanan Kerja ( Job Insecurity) secara simultan berpengaruh signifikan terhadap Intensi Keluar (Turnover Intention) pada PT. Asia Petrocom Services (APS) Duri?

\section{Tujuan Penelitian}

\begin{tabular}{lrr}
\multicolumn{1}{c}{ Tujuan } & penelitian & tentang \\
Pengaruh & Kepuasan & Kerja, \\
Komitmen & Organisasi & Dan \\
Ketidakamanan & Kerja & (Job
\end{tabular}
Insecurity) Terhadap Intensi Keluar (Turnover Intention) Pada PT. Asia Petrocom Services (APS) Duri adalah :

1. Untuk mengetahui dan menganalisa apakah Kepuasan Kerja secara parsial berpengaruh signifikan terhadap Intensi Keluar (Turnover Intention)pada PT. Asia Petrocom Services (APS) Duri

2. Untuk mengetahui dan menganalisa apakah Kepercayaan Terhadap Organisasi (Trust) 
secara parsial berpengaruh signifikan terhadap Intensi Keluar (Turnover Intention) pada PT. Asia Petrocom Services (APS) Duri

3. Untuk mengetahui dan menganalisa apakah Ketidakamanan Kerja (Job Insecurity) secara parsial berpengaruh signifikan terhadap Intensi Keluar (Turnover Intention) pada PT. Asia Petrocom Services (APS) Duri

4. Untuk mengetahui dan menganalisa apakah Kepuasan Kerja, Kepercayaan Terhadap Organisasi (Trust) dan Ketidakamanan Kerja (Job Insecurity) secara simultan berpengaruh signifikan terhadap Intensi Keluar (Turnover Intention) pada PT. Asia Petrocom Services (APS) Duri

\section{TINJAUAN PUSTAKA}

Menurut Lum et.al dalam Andini (2006) intensi keluar (tunover intention) adalah keinginan seseorang untuk keluar organisasi, yaitu evaluasi mengenai posisi seseorang saat ini berkenaan dengan ketidakpuasan dapat memicu keinginan seseorang untuk keluar dan mencari pekerjaan lain. Dapat disimpilkan turnover intention adalah keinginan karyawan atau niat karyawan untuk pindah/berhenti melakukan pekerjaan atau keluar dari organisasi.

\section{Faktor-Faktor yang \\ Mempengaruhi Intensi Keluar (Turnover Intention)}

Menurut Elsa Frischa Wijaya(2010) terdapat banyak faktor yang membuat individu memiliki keinginan untuk berpindah / turnover intention. Faktor-faktor tersebut diantaranya adalah: $a$. Kepuasan kerja, $b$. Komitmen organisasi dari karyawan, c. Kepercayaan terhadap organisasi, d. Job insecurity.

Hal ini juga sejalan dengan pendapat bebrapa para ahli tentang faktor yang mempengaruhi turnover intention diantaranya adalah:

a. Kepuasan Kerja

Karyawan dengan kepuasan kerja akan merasa senang dan bahagia dalam melakukan pekerjaannya dan tidak berusaha mengevaluasi alternatif pekerjaan lain. Sebaliknya karyawan yang merasa tidak puas dalam pekerjaannya cenderung mempunyai pikiran untuk keluar, mengevaluasi alternatif pekerjaan lain, dan berkeinginan untuk keluar karena berharap menemukan pekerjaan yang lebih memuaskan ditingkat individual (Mobley et. al., 1979; Muchinsky \& Tuttle, 1979; Porter \& Steers, 1973; Price; 1977).

b. Komitmen Organisasi Dari Karyawan

Komitmen mengacu pada respon emosional (affective) individu kepada keseluruhan organisasi, sedangkan kepuasan mengarah pada respon emosional atas aspek khusus dari pekerjaan (Williams \& Hazer, 1986).
c. Kepercayaan
Organisasi 
Penelitian yang dilakukan oleh Pasewark dan Strawser (1996) dalam Suwandi dan Indriartoro (1999) menguji model turnover dengan menggunakan konstruk kepercayaan organisasional. Variabel ini ditemukan hanya mempengaruhi keinginan berpindah secara tidak langsung melalui komitmen

d. Job Insecurity

Studi yang dilakukan oleh Barling dan Kelloway dalam Probst (2001) menunjukkan adanya kaitan antara job insecurity danturnover intention.

2. Indikator Intensi Keluar (Turnover Intention)

Aspek-aspek dari intensi turnover yang dijelaskan oleh Mobley dalam Ajagbe, dkk (2012) yaitu :
a. Thingking of quiting (mempertimbangkan untuk meninggalkan organisasi)
b. Intention to search (keinginan untuk mencari kerja diluar organisasi)
c. Intention to quit (keputusan untuk meninggalkan organisasi)

Menurut (Booth dan Hamer, 2007) ada beberapa aspek yang dapat di gunakan untuk melakukan pengukuran terhadap turnover intention yang terdiri dari Tingkat komitmen, Kepuasan kerja, Dukungan manajemen, Pengembangan karir dan Peningkatan kerja.

\section{Kepuasan Kerja}

\section{a. Pengertian Kepuasan Kerja}

Menurut Rifai dan Sagala
(2011) kepuasan kerja merupakan suatu sifat individual. Setiap individu mempunyai tingkat kepuasan yang berbeda, semakin tinggi penilaian yang di rasakan individu, makin tinggi kepuasannya terhadap kegiatan tersebut. Hal ini sejalan dengan pendapat yang di kemukakan oleh Robbins (2007) kepuasan kerja adalah suatu perasaan positif tentang pekerjaan seseorang yang merupakan hasil dari sebuah evaluasi karakteristiknya. Dapat disimpulkan bahwa kepuasan kerja merupakan suatu perasaan yang dirasakan setiap individu baik itu merasakan senang atau tidak senang dan juga merasakan puas atau tidak puas didalam melakukan pekerjaannya tergantung dengan kondisi yang ada didalam perusahaannya.

\section{b. Teori Teori Kepuasan Kerja}

Kepuasan kerja pada dasarnya merupakan sesuatu yang bersifat individual. Setiap individu memiliki tingkat kepuasan yang berbeda, sesuai dengan sistem penilaian yang berlaku pada dirinya. Dengan demikian kepuasan merupakan evaluasi yang menggambarkan seseorang atas perasaan sikap senang atau tidak senang dan puas atau tidak puas dalam bekerja. Adapun teori-teori kepuasan kerja menurut beberapa ahli antara lain Teori Ketidaksesuaian (Discrevancy Theory), Teori Keadilan (Equity Theory) dan yang paling fenomenal adalah Teori 
Dua Faktor Herzberg Two Factor Theory).

\section{c. Indikator Kepuasan Kerja}

Terdiri dari: $a$. Balas jasa yang adil dan layak, $b$. Penempatan yang tepat sesuai dengan keahlian, $c$. Berat ringannya pekerjaan, $d$. Suasana dan lingkungan pekerjaannya, e. Peralatan yang menunjang pelaksanaan pekerjaan, $f$. Sikap peimpin dalam kepemimpinannya, $g$. Sifat pekerjaan monoton atau tidak

2. Kepercayaan

Organisasi (Trust)

a. Pengertian Kepercayaan Terhadap Organisasi (Trust)

Menurut (Moorman et al., 1992), dalam penelitian Yuchun, Xiyan, Wenan dan Xiaoxia (2010), kepercayaan adalah premis untuk memenuhi komitmen sementara komitmen adalah hasil dari kepercayaan. Hal ini secara luas telah dipahami dan disepakati bahwa komitmen organisasi dan kepercayaan merupakan variabel yang saling terkait. Bahkan beberapa pandangan yang berlaku mengatakan bahwa baik komitmen dan kepercayaan adalah proses yang mengalir yang diciptakan melalui interaksi simbolik dengan pelaku organisasi di mana interaksi dengan pelaku, dari waktu ke waktu akan mempengaruhi komitmen terhadap organisasinya (Tyler \& Doerfel, 2006), dalam Rachid Zeffane, Syed A Tipu, James C Ryan (2011). b. Dimensi Organizational Trust Menurut Robbins dan Judge (2008), terdapat 5 dimensi dalam hal kepercayaan organisasi antara lain:

1) Integritas, merujuk pada kejujuran dan keadaan sebenarnya. Dari kelima dimensi, ini tampaknya yang paling penting, bila seseorang menilai sifat dapat dipercaya dari pihak lain. "Tanpa pemahaman karakter moral dan kejujuran dasar orang lain, dimensi kepercayaan lain tidak akan ada artinya.

2) Kompetensi, mencakup pengetahuan serta keahlian teknis dan antarpersonal individu.

3) Konsistensi, terkait dengan keandalan individu, prediktabilitas, dan membuat penilaian pada diri seseorang dalam menangani situasi.

4) Kesetiaan, adalah kesediaan untuk melindungi dan menyelamatkan muka orang lain.

5) Keterbukaan, adalah bersikap terbuka dan transparan dalam memberikan suatu kebenaran seutuhnya.

3. Ketidakamanan Kerja (Job Insecurity)

a. Pengertian Ketidakamanan Kerja (Job Insecurity)

Menurut Fiksenbaum dkk dalam Mizar (2008) menyatakan bahwa terdapat pengaruh antara ketidakamanan kerja dengan intensi pindah kerja karyawan, 
karena ketidakamanan kerja yang terjadi secara terus menerus akan mempengaruhi kondisi psikologis karyawan. Jika masalah rasa tidak aman dalam bekerja terus menerus dihadapi karyawan, maka akan menstimulasi munculnya keinginan untuk berpindah kerja atau turnover intention. Semakin tinggi job insecurity akan menyebabkan tingginya tingkat turnover intention.

b. Indikator Ketidakamanan Kerja (Job Insecurity)

Komponen yang mengakibatkan timbulnya ketidakaman kerja (job insecurty) menurut Grennhalgh dan Rosenblatt dalam Mizar (2008) adalah :

1) Tingkat ancaman yang dirasakan karyawan mengenai aspek-aspek pekerjaan seperti kemungkinan untuk mendapat

promosi,mempertahankan tingkat gaji yang sekarang atau memperoleh kenaikan gaji.

2) Arti pekerjaan itu sebagai individu,

Seberapa pentingnya aspek pekerja tersebut bagi individu mempengaruhi tingkat insecure atau rasa tidak amannya.

3) Tingkat ancaman yang kemungkinan terjadi mempengaruhi keseluruhan kerja individu seperti tingkat bahaya pada pekerjaan yang dibebankan atau perusahaan bangkrut dan tutup yang mampu berpengaruh terhadap seluruh pekerjaannya.

4) Tingkat kepentingan yang dirasakan individu mengenai potensi setiap peristiwa tersebut.

\section{Pandangan Islam}

\section{Pandangan Islam Tentang Intensi Keluar (Turnover Intention)}

Pandangan islam tentang intensi keluar (turnover intention) terdapat dalam QS. Al-Qashash ayat 77 yaitu:

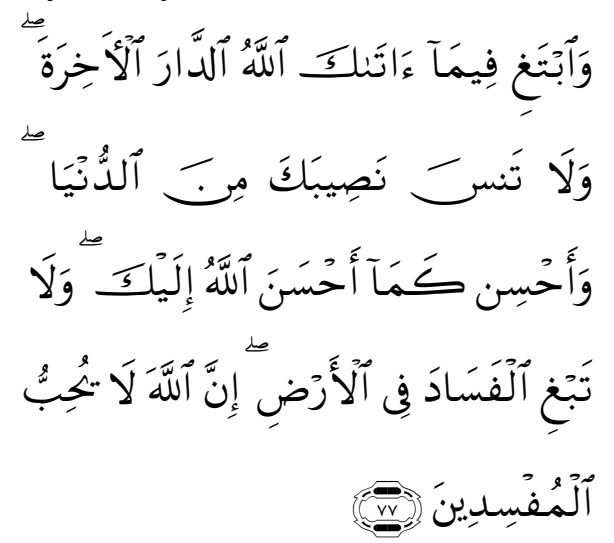

Artinya:

"Dan carilah pada apa yang telah dianugerahkan Allah kepadamu (kebahagiaan) negeri akhirat, dan janganlah kamu melupakan bahagianmu dari (kenikmatan) duniawi dan berbuat baiklah (kepada orang lain) sebagaimana Allah telah berbuat baik, kepadamu, dan janganlah kamu berbuat kerusakan di (muka) bumi. Sesungguhnya Allah tidak menyukai orang-orang yang berbuat kerusakan"'(Q.S AlQashash : 77)

\section{Pandangan Islam Tentang} Kepuasan Kerja

Pandangan islam mengenai kepuasan kerja tencantum di dalam QS. Thaha ayat 117-119: 


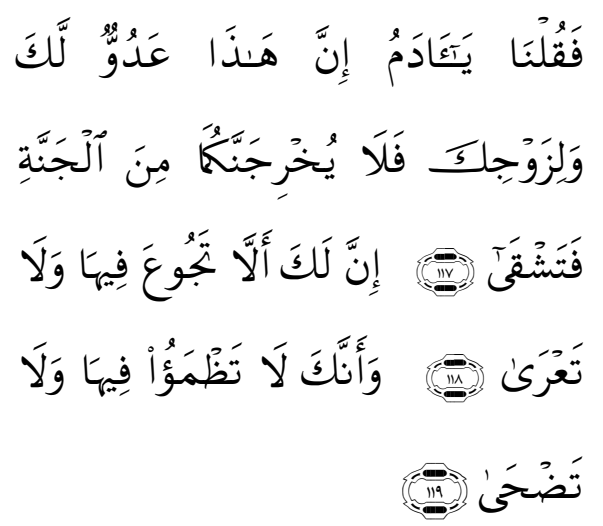

Artinya:

"Maka Kami berkata: "Hai Adam, sesungguhnya ini (iblis) adalah musuh bagimu dan bagi isterimu, maka sekali-kali janganlah sampai ia mengeluarkan kamu berdua dari surga, yang menyebabkan kamu menjadi celaka. Sesungguhnya kamu tidak akan kelaparan di dalamnya dan tidak akan telanjang. dan sesungguhnya kamu tidak akan merasa dahaga dan tidak (pula) akan ditimpa panas matahari di dalamnya" (QS. Thaha:117-119).

\section{Pandangan Islam Tentang Kepercayaan Terhadap Organisasi (Trust)}

Islam mengajarkan kita bekerja dengan memegang teguh kepercayaan yang telah diberikan dan hendaklah bekerja dengan baik sesuai dengan tujuan perusahaan. Hal ini sesuai dengan firman Allah SWT dalam QS. An nisa ayat 146.

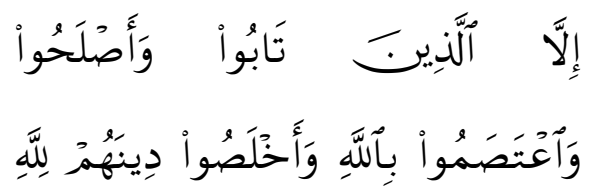

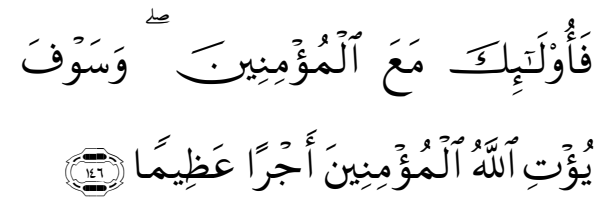

Artinya : "Kecuali orangorang yang taubat dan mengadakan perbaikan dan berpegang teguh pada (agama) Allah dan tulus ikhlas (mengerjakan) agama mereka karena Allah. Maka mereka itu adalah bersama-sama orang yang beriman dan kelak Allah akan memberikan kepada orang-orang yang beriman pahala yang besar" (QS. An nisa : 146)

4. Pandangan Islam Tentang Ketidakamanan Kerja (Job Insecurity)

Ketidakamanan kerja memang sering menjadi bahan pikiran seorang manusia dalam bekerja, namun sudah jelas apapun yang dikerjakan pastinya sudah ada yang melihat dan hal ini sesuai dengan firman Allah SWT dalam QS. Al-An'am ayat 132.

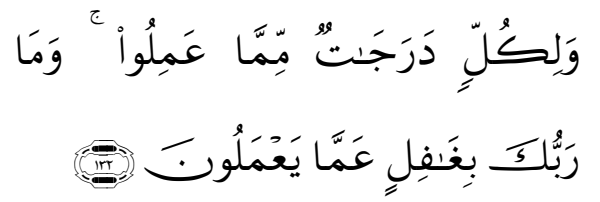

Artinya:

"Dan masing-masing orang memperoleh derajat-derajat (seimbang) dengan apa yang dikerjakannya. Dan Tuhanmu tidak lengah dari apa yang mereka kerjakan" (QS. AlAn'am : 132)

\section{Penelitian Terdahulu}

1. Yunita Zahra Dan Emmi Mariatin (2006) Hubungan Kepercayaan Karyawan Pada Organisasi Terhadap Komitmen Kepada 
Organisasi Pada PT. Bank X. Penelitian ini mengeksaminasi peran kepercayaan karyawan kepada organisasi terhadap komitmen kepada organisasi. Hasil penelitian ini menunjukkan bahwa semakin tinggi kepercayaan karyawan kepada organisasi diikuti oleh peningkatan identifikasi dan keterlibatan pegawai terhadap organisasi menunjukkan pentingnya membangun kepercayaan karyawan terhadap organisasi

2. Mohammad Hanafiah (2014) Pengaruh Kepuasan Kerja Dan Ketidakamanan Kerja ( $\mathrm{Job}$ Insecurity) Terhadap Intensi Pindah Kerja (Turnover Intention) Pada PT. Buma Desa Suaran Kecamatan Sambaliung Kabupaten Berau. Hasil penelitian membuktikan Terdapat Pengaruh Antara Kepuasan Kerja Dan Ketidakamanan Kerja ( $\mathrm{Job}$
Insecurity) Dengan Intensi Pindah Kerja (Turnover Intention) Pada Karyawan PT. Buma Desa Suaran Kecamatan Sambaliung

Kabupaten Berau.

\section{Variabel Penelitian}

Adapun yang menjadi variabel dalam penelitian ini adalah:

$\mathrm{X}_{1}$ : Kepuasan Kerja

$\mathrm{X}_{2}$ : Kepercayaan Terhadap Organisasi (Trust)

$\mathrm{X}_{3}$ : Ketidakamanan Kerja (Job Insecurity)

Y : Intensi Keluar(Turnover Intention)

\section{Definisi dan Konsep Operasional Variabel Penelitian}

Variabel-variabel yang akan didefenisi adalah semi variabel yang terkandung dalam hipotesis, yang bertujuan untuk memudahkan membuat kuisioner. Adapun konsep operasional variabel pada penelitian ini adalah sebagai berikut: 
Tabel 2 : Definisi Dan Konsep Operasional Variabel Penelitian

\begin{tabular}{|c|c|c|c|}
\hline Variabel & Definisi & Indikator & Skala \\
\hline $\begin{array}{l}\text { Intensi Keluar } \\
(\text { Turnover } \\
\text { Intention)(Y) }\end{array}$ & $\begin{array}{l}\text { Turnover intention adalah } \\
\text { kecendrungan atau niat } \\
\text { karyawan untuk berhenti } \\
\text { bekerja dari pekerjaannya } \\
\text { secara sukarela menurut } \\
\text { pilihannya sendiri.Zeffane } \\
\text { dalam Sulistyawati (2008) }\end{array}$ & $\begin{array}{l}\text { a. Thingking of } \\
\text { quiting(mempertimbangkan } \\
\text { untuk meninggalkan organisasi) } \\
\text { b. Intention to search (keinginan } \\
\text { untuk mencari kerja di luar } \\
\text { organisasi) } \\
\text { c. Intention to quit(keputusan } \\
\text { untuk meninggalkan organisasi) } \\
\text { Mobley dalam Ajagbe, dkk } \\
\text { (2012) }\end{array}$ & Likert \\
\hline $\begin{array}{l}\text { Kepuasan } \\
\text { Kerja }\left(X_{1}\right)\end{array}$ & $\begin{array}{l}\text { Kepuasan kerja merupakan } \\
\text { suatu sifat individual. Setiap } \\
\text { individu mempunyai tingkat } \\
\text { kepuasan yang berbeda, } \\
\text { semakin tinggi penilaian } \\
\text { yang di rasakan individu, } \\
\text { makin tinggi kepuasannya } \\
\text { terhadap kegiatan tersebut. } \\
\text { (Rivai dan Sagala, 2011) }\end{array}$ & $\begin{array}{l}\text { a. Balas jasa yang adil dan layak } \\
\text { b. Penempatan yang tepat sesuai } \\
\text { dengan keahlian } \\
\text { c. Berat ringannya pekerjaan } \\
\text { d. Suasana ligkungan pekerjaan } \\
\text { e. Peralatan yang menunjang } \\
\text { pelaksanaan pekerjaan } \\
\text { f. Sikap pemimpin dalam } \\
\text { kepemimpinannya } \\
\text { g. Sifat pekerjaan monoton atau } \\
\text { tidak (Hasibuan, 2005) }\end{array}$ & Likert \\
\hline $\begin{array}{l}\text { Kepercayaan } \\
\text { Terhadap } \\
\text { Organisasi } \\
\left(\mathrm{X}_{2}\right)\end{array}$ & $\begin{array}{l}\text { Kepercayaan organisasi } \\
\text { merupakan kepercayaan dari } \\
\text { seorang individu atau } \\
\text { kelompok secara keseluruhan } \\
\text { bahwa individu atau } \\
\text { organisasi akan melakukan } \\
\text { segala upaya dengan itikad } \\
\text { baik dalam bertindak sesuai } \\
\text { dengan komitmennya untuk } \\
\text { memberikan yang terbaik } \\
\text { dimana pun ia bekerja } \\
\text { (Robbins, 2008) }\end{array}$ & $\begin{array}{l}\text { a.Integritas } \\
\text { b.Kompetensi } \\
\text { c.Konsistensi } \\
\text { d.Kesetiaan } \\
\text { e.Keterbukaan. Robbins dan } \\
\quad \text { Judge (2008) } \\
\\
\end{array}$ & Likert \\
\hline $\begin{array}{l}\text { Ketidak } \\
\text { amanan Kerja } \\
(\text { Job } \\
\text { Insecurity })\left(\mathrm{X}_{3}\right.\end{array}$ & 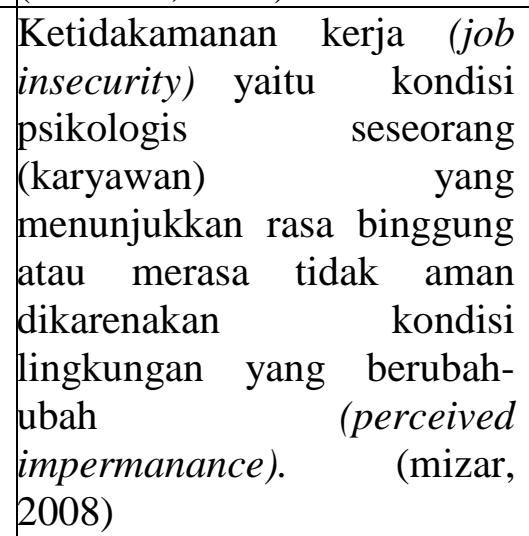 & 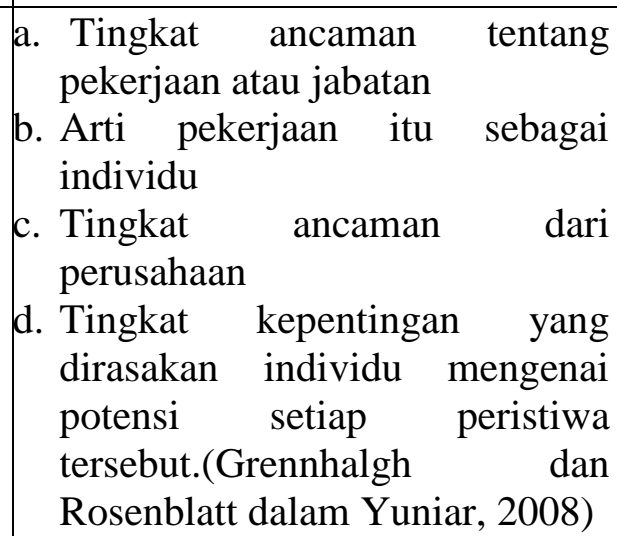 & Likert \\
\hline
\end{tabular}




\section{Kerangka Pemikiran Penelitian}

Berikut ini dapat digambarkan kerangka pemikiran yang dijadikan dasar pemikiran dalam penelitian ini.
Kerangka tersebut merupakan dasar pemikiran dalam melakukan analisis dalam penelitian ini:

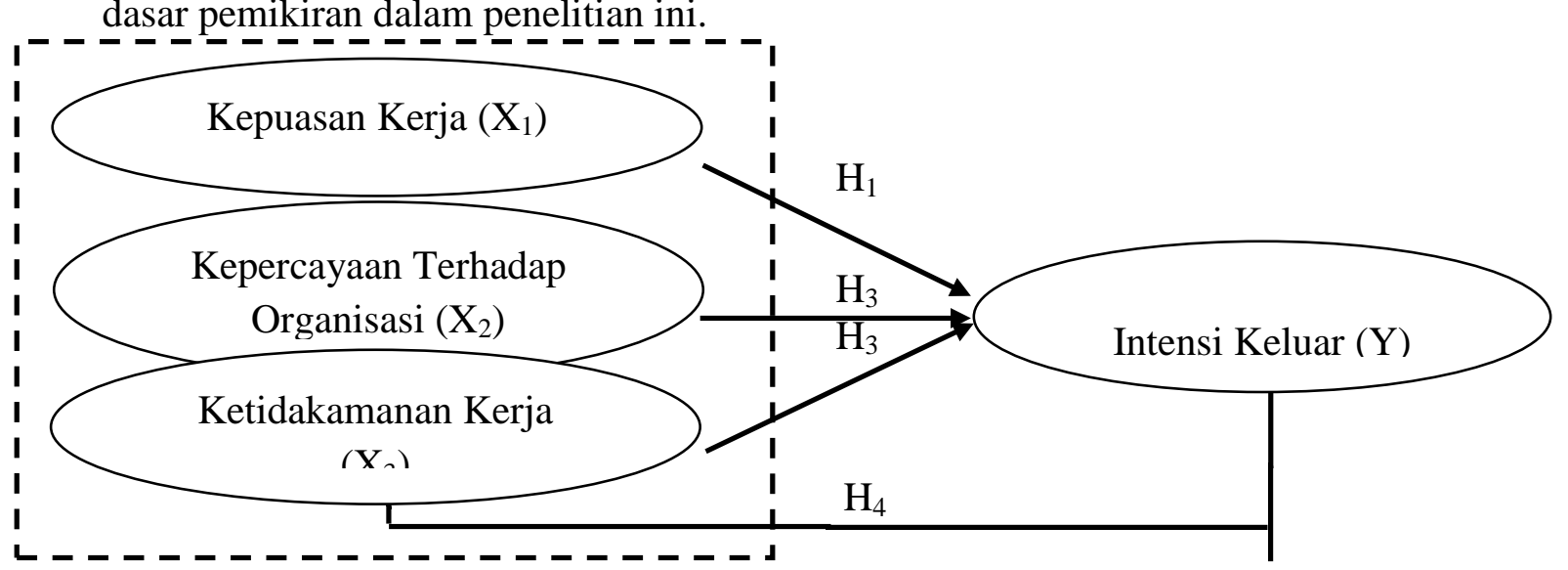

Gambar 1: Kerangka Pemikiran Penelitian

Pengaruh Kepuasan Kerja $\left(\mathbf{X}_{1}\right)$, Kepercayaan Terhadap Organisasi $\left(\mathbf{X}_{2}\right)$ dan Ketidakamanan Kerja (job insecurity) $\left(\mathbf{X}_{3}\right)$ Terhadap Intensi Keluar (Turnover Intention) (Y)

Sumber: Mobley (1977), ( Mobley et. al., 1979; Muchinsky \& Tuttle, 1979; Porter \& Steers, 1973; Price; 1977), Swan, John E, I Trawick David R. Rink dan Jenny J. Robert (1988), Pasewark dan Strawser (1996) dalam Suwandi dan Indriartoro (1999), Barling dan Kelloway dalam Probst (2001), Elsa Frischa Wijaya (2010)

\section{Hipotesis}

Hipotesis dari penelitian ini adalah:

1. Diduga kepuasan kerja secara parsial berpengaruh signifikan terhadap intensi keluar (turnover intention) pada PT. Asia Petrocom Services (APS) Duri.

2. Diduga kepercayaan terhadap organisasi (trust) organisasi secara parsial berpengaruh signifikan terhadap intensi keluar (turnover intention) pada PT. Asia Petrocom Services (APS) Duri.

3. Diduga ketidakamanan kerja (job insecurity) secara parsial berpengaruh signifikan terhadap intensi keluar (turnover intention) pada PT. Asia Petrocom Services (APS) Duri.

4. Diduga kepuasan kerja, kepercayaan terhadap organisasi (trust) dan ketidakamanan kerja (job insecurity)secara simultan berpengaruh signifikan terhadap intensi keluar (turnover intention) pada PT. Asia Petrocom Services (APS) Duri.

\section{METODE PENELITIAN \\ Variabel Penelitian}

Penelitian ini terdiri dari 3 (tiga) variabel bebas (Independent Variabel) yaitu Kepuasan Kerja, Kepercayaan Terhadap Organisasi (Trust) dan Ketidakamanan Kerja serta 1 (satu) variabel terikat (Dependent Variabel) yaitu Intensi Keluar (Turnover Intention)

\section{Lokasi Penelitian}

Dalam penelitian ini, peneliti melakukan studi empiris (survey) pada PT. Asia Petrocom Services (APS) Duri. 


\section{Populasi dan Sampel}

Populasi dalam penelitian ini adalah karyawan PT. Asia Petrocom Services (APS) Duri berjumlah 241 Orang dan Sampel menggunakan Rumus Slovin dengan perbandingan $10 \%$ yaitu menjadi 71 Orang.

\section{Metode Pengumpulan Data}

Data diperoleh dengan memberikan kuesioner kepada 71 responden dan dokumentasi untuk mengetahui jumlah pegawai serta wawancara untuk kelengkapan data.

\section{HASIL PENELITIAN Analisis Data}

Penelitian ini menggunakan analisis regresi linier berganda untuk mengetahui besarnya pengaruh variabel independen yaitu kepuasan kerja, Kepercayaan Terhadap Organisasi (Trust) dan ketidakamanan kerja (job insecurity )terhadap variabel dependen yaitu intensi keluar (turnover intention) pada karyawan PT. Asia Petrocom Services (APS) Duri.

\section{Uji Validitas}

Pengolahan validitas instrumen Regresi berganda yang merupakan dasar dari perhitungan koefisien beta kemudian dibantu dengan software pengolahan data Statistical Package for Social Sciencec (SPSS) 17.0. Berdasarkan hasil pengujian data terlihat nilai nilai corrected itemtotal correlation lebih besar dibandingkan 0,30 maka semua variabel dinyatakan valid dengan jumlah responden 71 orang karyawan.

\section{Uji Multikolinearitas}

Dari hasil perhitung, terlihat bahwa nilai VIF yang ada tidak lebih besar dari 10 dan sama dimana nilai VIF untuk $X_{1}=1.299$, nilai VIF untuk $\mathrm{X}_{2}=1.292$ dan nilai VIF untuk $\mathrm{X}_{3}=1.074$, jadi dapat dikatakan tidak ada persoalan multikolinearitas pada model yang dibuat. Terlihat pada tabel 3:

Tabel 3. Uji Multikolinieritas

Coefficients $^{\mathbf{a}}$

\begin{tabular}{|c|c|c|c|c|c|c|c|}
\hline \multirow[t]{2}{*}{ Model } & \multicolumn{2}{|c|}{$\begin{array}{c}\text { Unstandardized } \\
\text { Coefficients }\end{array}$} & \multirow{2}{*}{$\begin{array}{c}\begin{array}{l}\text { Standardized } \\
\text { Coefficients }\end{array} \\
\text { Beta }\end{array}$} & \multirow[t]{2}{*}{$\mathrm{T}$} & \multirow[t]{2}{*}{ Sig. } & \multicolumn{2}{|c|}{$\begin{array}{c}\text { Collinearity } \\
\text { Statistics }\end{array}$} \\
\hline & $\mathrm{B}$ & $\begin{array}{l}\text { Std. } \\
\text { Error }\end{array}$ & & & & Tol & VIF \\
\hline 1 (Constant) & 14.426 & 1.534 & & 9.406 & .000 & & \\
\hline $\mathrm{x} 1$ & -.270 & .040 & -.591 & -6.734 & .000 & .770 & 1.299 \\
\hline $\mathrm{x} 2$ & -.128 & .058 & -.193 & -2.209 & .031 & .774 & 1.292 \\
\hline $\mathrm{x} 3$ & .230 & .093 & .198 & 2.479 & .016 & .931 & 1.074 \\
\hline
\end{tabular}

Sumber : Data Olahan Hasil Penelitian, 2016.

\section{Uji Asumsi Klasik}

Uji Normalitas

\begin{tabular}{llr}
\multicolumn{1}{c}{ Melalui } & Uji & Normalitas \\
variabel & Kepuasan & Kerja, \\
Kepercayaan & Terhadap & Organisasi \\
(Trust) dan & Ketidakamanan & Kerja
\end{tabular}

(Job Inssecurity) serta Intensi Keluar (Turnover Intention) memenuhi asumsi normalitas, karena data menyebar disekitar garis diagonal dan mengikuti arah garis diagonal. 


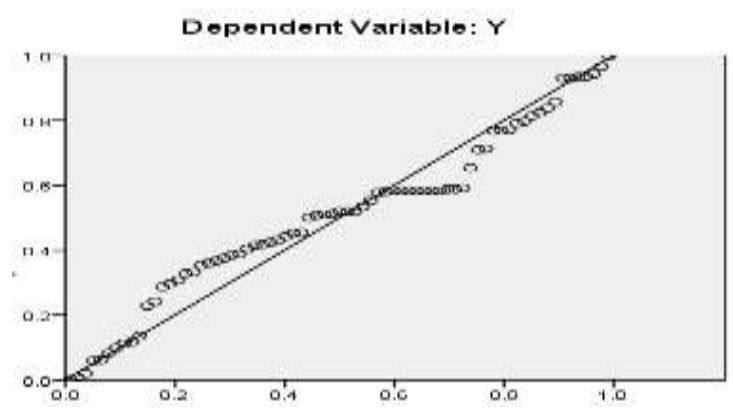

Gambar 2: Grafik Kurva Normalitas

Uji Autokorelasi

Untuk menguji apakah ada masalah autokorelasi dalam persamaan regresi linier berganda, dapat dilihat pada tabel 4

Tabel 4. Uji Autokorelasi

Model Summary ${ }^{\text {b }}$

\begin{tabular}{|l|c|c|c|c|r|}
\hline Model & $\mathrm{R}$ & $\mathrm{R}$ Square & $\begin{array}{c}\text { Adjusted R } \\
\text { Square }\end{array}$ & $\begin{array}{c}\text { Std. Error of the } \\
\text { Estimate }\end{array}$ & Durbin-Watson \\
\hline 1 & $.776^{\mathrm{a}}$ & .602 & .584 & 1.39488 & 1.999 \\
\hline \multicolumn{5}{l}{ a. Predictors: (Constant), $\mathrm{x}_{3}, \mathrm{x}_{2}, \mathrm{x}_{1}$} \\
\hline
\end{tabular}

Sumber: Data olahan SPSS, 2016.

\section{Uji Heteroskedastisitas}

Berdasarkan gambar 3, tidak ada persoalan heteroskedastisitas pada model yang dibuat, sehingga model ini layak dipakai untuk memprediksi variabel Kepuasan
Kerja, Kepercayaan Terhadap

Organisasi (Trust) dan

Ketidakamanan Kerja (Job Inssecurity) serta Intensi Keluar (Turnover Intention) karyawan.

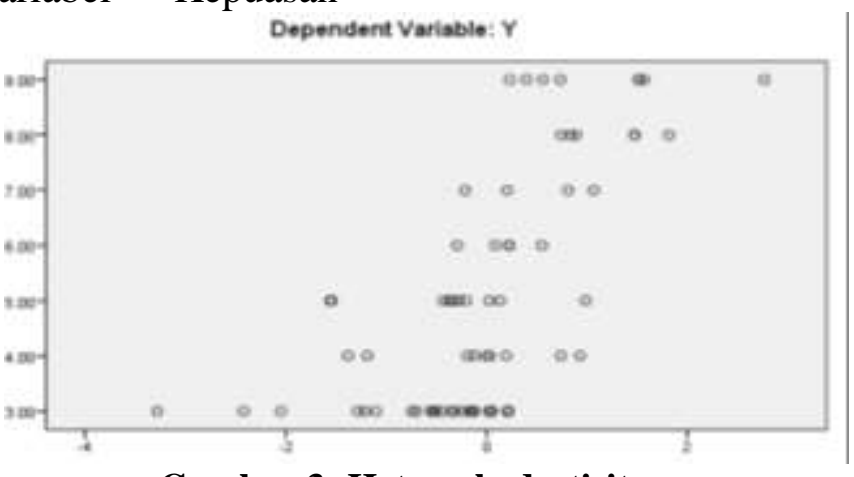

Gambar 3: Heteroskedastisitas

\section{PEMBAHASAN}

Pembuktian hipotesis secara total digunakan untuk melihat pengaruh variabel bebas secara bersama-sama yaitu Kepuasan Kerja, Kepercayaan Terhadap Organisasi
(Trust) dan Ketidakamanan Kerja (Job Inssecurity) serta Intensi Keluar (Turnover Intention) karyawan. Berdasarkan hasil perhitungan, maka diperoleh data-data perhitungan sebagai berikut: 
Tabel 5.

Koefisien Regresi tentang Kepuasan Kerja, Kepercayaan Terhadap Organisasi (Trust) Dan Ketidakamanan Kerja (Job Insecurity) terhadap Intensi Keluar (Turnover Intention)

\begin{tabular}{|c|c|c|c|c|c|c|}
\hline \multirow{2}{*}{\multicolumn{2}{|c|}{ Model }} & \multicolumn{5}{|c|}{ ANOVA $^{b}$} \\
\hline & & Sum of Squares & Df & Mean Square & $\mathrm{F}$ & Sig. \\
\hline \multirow[t]{3}{*}{1} & Regression & 197.413 & 3 & 65.804 & 33.820 & $.000^{\mathrm{a}}$ \\
\hline & Residual & 130.362 & 67 & 1.946 & & \\
\hline & Total & 327.775 & 70 & & & \\
\hline \multicolumn{7}{|c|}{ a. Predictors: (Constant), $\mathrm{x} 3, \mathrm{x} 2, \mathrm{x} 1$} \\
\hline \multicolumn{7}{|c|}{ b. Dependent Variable: Y } \\
\hline
\end{tabular}

Dari tabel 5 di atas diketahui $F_{\text {hitung }}$ sebesar 33,820 dengan signifikansi 0,000. Dan diperoleh $\mathrm{F}_{\text {tabel }}$ statistik sebesar 3,974.Dengan demikian diketahui $\mathrm{F}_{\text {hitung }}(33,820)>$ $F_{\text {tabel }}(3,978)$ dengan Sig. $(0,000)<$ (trust) dan ketidakamanan kerja (job insecurity) memiliki pengaruh terhadap intensi keluar (turnover intention) pada PT.Asia Petrocom Service (APS) Duri.

0,05 . Artinya adalah kepuasan kerja, kepercayaan terhadap organisasi

Tabel 6. Hasil Koefisien Determinasi Model Summary ${ }^{\text {b }}$

\begin{tabular}{|l|r|r|r|r|r|}
\hline Model & $\mathrm{R}$ & $\mathrm{R}$ Square & $\begin{array}{c}\text { Adjusted R } \\
\text { Square }\end{array}$ & $\begin{array}{c}\text { Std. Error of the } \\
\text { Estimate }\end{array}$ & Durbin-Watson \\
\hline 1 & $.776^{\mathrm{a}}$ & .602 & .584 & 1.39488 & 1.999 \\
\hline
\end{tabular}

a. Predictors: (Constant), x3, x2, x1

b. Dependent Variable: Y

Adapun angka Adjusted $\mathrm{R}$ square $\left(\mathrm{R}^{2}\right)$ adalah sebesar 0,584 , menunjukkan bahwa $58.4 \%$ intensi keluar (turnover intention) karyawan PT.Asia Petrocom Service (APS) Duri bisa diterangkan dengan variabel kepuasan kerja, kepercayaan terhadap organisasi (trust) dan ketidakamanan kerja (job insecurity). Sedangkan sisanya $42.6 \%$ dapat diterangkan oleh variabel lain yang tidak diteliti pada penelitian ini.

Tabel 7.Uji Regresi Linier Berganda

Coefficients $^{\mathrm{a}}$

\begin{tabular}{|c|c|c|c|c|c|c|c|c|}
\hline \multirow{2}{*}{\multicolumn{2}{|c|}{ Model }} & \multicolumn{2}{|c|}{$\begin{array}{l}\text { Unstandardized } \\
\text { Coefficients }\end{array}$} & $\begin{array}{l}\text { Standardized } \\
\text { Coefficients }\end{array}$ & \multirow[t]{2}{*}{$\mathrm{T}$} & \multirow[t]{2}{*}{ Sig. } & \multicolumn{2}{|c|}{$\begin{array}{l}\text { Collinearity } \\
\text { Statistics }\end{array}$} \\
\hline & & $\mathrm{B}$ & Std. Error & Beta & & & Tol & VIF \\
\hline \multirow[t]{4}{*}{1} & (Constant) & 14.426 & 1.534 & & 9.406 & .000 & & \\
\hline & $\mathrm{x} 1$ & -.270 & . 040 & -.591 & -6.734 & .000 & .770 & 1.299 \\
\hline & $\mathrm{x} 2$ & -.128 & .058 & -.193 & -2.209 & .031 & .774 & 1.292 \\
\hline & $\mathrm{x} 3$ & .230 & .093 & .198 & 2.479 & .016 & .931 & 1.074 \\
\hline
\end{tabular}


Persamaan Regresi Berganda:

$$
\begin{aligned}
Y= & a+b_{1} X_{1}+b_{2} X_{2+} b_{3} X_{3+} e \\
Y= & 14,426-0,270 X_{1}-0,128 X_{2}+ \\
& 0,230 X_{3}+e
\end{aligned}
$$

Arti angka-angka dalam persamaan regresi diatas adalah :

1. Nilai konstanta (a) sebesar 14,426. Artinya adalah apabilakepuasan kerja, kepercayaan terhadap organisasi (trust), dan ketidakamanan kerja (job insecurity) diasumsikan bernilai nol (0), maka intensi keluar (turnover intention) sebesar 2,073 .

2. Nilai koefisien regresi $-0,270$ menyatakan bahwa jika kepuasan kerja mengalami peningkatan 1 satuan, maka intensi keluar (turnover intention) akan mengalami penurunan sebesar 0,270 .

3. Nilai koefisien regresi $-0,128$ menyatakan bahwa jika kepercayaan terhadap organsisasi (trust) mengalami peningkatan 1 satuan, maka intensi keluar (turnover intention) akan mengalami penurunan sebesar 0,128 .

4. Nilai koefisien regresi 0,230 menyatakan bahwa jika ketidakamanan pekerjaan mengalami peningkatan 1 satuan, maka intensi keluar (turnover intention) akan mengalami peningkatan sebesar 0,230.

5. Standar error (e) merupakan variabel acak dan mempunyai distribusi profitabilitas yang mewakili semua faktor yang mempunyai pengaruh terhadap $\mathrm{Y}$ tetapi tidak dimasukan dalam persamaan.

\section{PENUTUP}

\section{Kesimpulan}

1. Kepuasan kerja $\left(\mathrm{X}_{1}\right)$ terhadap variabel intensi keluar (turnover intention) (Y) menunjukan nilai $t_{\text {hitung }}(-6,734)<t_{\text {tabel }}(-1,994)$ dengan nilai signifikasi yang dihasilkan sebesar 0,000 masih berada dibawah 0,05 , hal ini menunjukan bahwa kepuasan kerja $\left(\mathrm{X}_{1}\right)$ memiliki pengaruh negatif dan signifikan terhadap intensi keluar (turnover intention) (Y).

2. Kepercayaan terhadap organisasi (trust) $\left(\mathrm{X}_{2}\right)$ terhadap variabel intensi keluar (turnover intention) (Y) menunjukan nilai $t_{\text {hitung }}$ ($2,209)<t_{\text {tabel }}(-1,990)$ dengan nilai signifikasi yang dihasilkan sebesar 0,031 masih berada dibawah 0,05, hal ini menunjukan bahwa Kepercayaan terhadap organisasi (trust) $\left(\mathrm{X}_{2}\right)$ memiliki pengaruh negatif dan signifikan terhadap intensi keluar (turnover intention) (Y).

3. Ketidakamanan kerja (job insecurity) $\left(\mathrm{X}_{3}\right)$ terhadap variabel intensi keluar (turnover intention) (Y) menunjukan nilai $t_{\text {hitung }}$ $(2,479)>t_{\text {tabel }}(1,990)$ dengan nilai signifikasi yang dihasilkan sebesar 0,016 masih berada dibawah 0,05, hal ini menunjukan bahwa ketidakamanan kerja (job insecurity) $\left(\mathrm{X}_{2}\right)$ memiliki pengaruh postif dan signifikan terhadap intensi keluar (turnover intention) (Y).

4. Nilai F hitung sebesar 33,820 dengan signifikansi 0,000 . F tabel dapat diperoleh dari $F$ tabel statistik sebesar 3,974. Dengan demikian diketahui $\mathrm{F}$ hitung $(33,820)>\mathrm{F}$ tabel $(3,978)$ dengan 
Sig. $(0,000)<0,05$ artinya adalah kepuasan kerja, kepercayaan terhadap organisasi (trust) dan ketidakamanan kerja (job insecurity) memiliki pengaruh terhadap intensi keluar (turnover intention) pada PT. Asia Petrocom Service (APS) Duri.

5. Nilai korelasi atau $\mathrm{R}$ sebesar 0,776 atau $77,6 \%$ artinya terdapat hubungan kepuasan kerja, Kepercayaan terhadap organisasi (trust) dan ketidakamanan kerja (job insecurity) terhadap intensi keluar (turnover intention) sebesar $77,6 \%$ dan nilai koefisien determinasi atau R Square sebesar 0,602 atau $60,2 \%$ artinya intensi keluar (turnover intention) dapat dijelaskan oleh kepuasan kerja, Kepercayaan terhadap organisasi (trust) dan ketidakamanan kerja (job insecurity) sebesar 60,2\% dan sisanya dipengaruhi oleh variabel lain.

\section{Saran}

1. PT. Asia Petrocom Service (APS) Duri harus lebih memperhatikan dan meningkatkan kepuasan yang dirasakan oleh para karyawannya dengan memberikan segala yang dibutuhkan karyawan seperti kompensasi yang dapat memenuhi kebutuhan dan sesuai dengan pekerjaan yang dibebankan karyawan.

2. PT. Asia Petrocom Service (APS) Duri lebih mengevaluasi dan memperbaiki kepercayaan yang sudah ada, agar menjadi lebih baik lagi dan bagi karyawan diharapkan memiliki tingkat kepercayaan yang baik juga terhadap perusahaan selama menjalani pekerjaan, sehingga akan menimbulkan hubungan timbal balik yang baik.

3. PT. Asia Petrocom Service (APS) Duri lebih memperhatikan tingkat keamanan kerja (job security) karyawannya pada saat melaksanakan pekerjaan yang bertujuan untuk membuat karyawan aman dalam melaksanakan pekerjaan dan diharapkan karyawan untuk lebih tinggi tingkat kepekaan terhadap perlengkapan keamanan yang digunakan.

4. Untuk peneliti selanjutnya hendaknya lebih dikembangkan lagi tentang faktor-faktor yang dapat mempengaruhi intensi keluar (turnover intention) karyawan.

\section{DAFTAR PUSTAKA}

Ajagbe, Long, Sulaeman,dan NorKhalil. 2012.JournalThe Approachesto IncreaseEmployee's Loyalty : AReviewonEmployees'Turnove $r$

Models.(http://eprints.covenant univercity.edu.ng. diakses 06 Oktober 2012.

Al-qur'an Surah Al-an'am ayat: 132, An Nisa ayat: 146, Thaha ayat: 117-119, Al-Qashash ayat: 77

Andini, Rita, 2006. Tesis : "AnalisisPengaruhKepuasanG aji, KepuasanKerja, KomitmenOrganisasionalTerh adap Turnover Intention". Program Studi MM, Program PascaSarjana, UniversitasDiponegoro, Semarang.JurnalRisetManajem enSains Indonesia (JRMSI) |Vol. 3, No. 1, 2012, 
(http://emprintis.

Undip.ac.id/15830, diakses 06 Juli 2010)

Booth, S. Hamer, K. 2007. Labour Turnover In The Retail Industry (Predicting The Role Of Individual, OrganisatioNal And Environmental Factors).International Journal Of Retail And Distribution Management . UK: Emerald Group Publishing Limited. Vol. 35 No.4 (289-307). (Online), (http://centau. reading.ac.uk/20657/)

Dessler, Gerry. 2005. Manajemen Sumber Daya Manusia. Alih Bahasa: Eli Tanya. Penyunting Bahasa: Budi Supriyanto. Jakarta. Indeks.

Elsa FrichaWijaya. 2010. Tesis : "Pengaruh Job Insecurity, KomitmenOrganisasi Dan KepuasanKerjaTerhadap Intention To Quit. S2 Unibraw".(Online),(http://ww w.academia.edu/12670462/pen garuh_job_insecuritykomitmen _karyawan_dan_kepuasan_kerj a_terhadap_intention_to_quit).

Hasibuan Malayu S.P. 2005. ManajemenSumberDayaManus ia.EdisiRevisi. BumiAksara. Jakarta..

Mizar, Yuniar, 2008. Tesis :"PengaruhFaktorKetidakama nanKerja (Job Insecurity) Dan KepuasanKerjaTerhadapNiatP indah (Turnover Itention) DenganKomitmenOrganisasio nalSebagaiVariabelIntervening ".SemarangMagister ManajemenUniversitasDipone goro. (E-Jurnal Manajemen Unud, Vol. 4, No. 4, 2015:1047-1066).
Mohammad, Hanafiah. 2014. PengaruhKepuasanKerjadanK etidakamananKerja (Job Insecurity) denganIntensiPindahKerja (Turnover)PadaKaryawan PT. BumaDesaSuaranKecamatanSa mbaliungKabupatenBerau.

(http://eJournal.Psikologi.fisipu nmul.ac.id/site/wpcontent/uplo ads/2014/02/my\%20jurnal\%20. 02-26-1402-05-22.pdf.Vol.1 (3): 303-312, diakses 26 Maret 2016)

Rifai, Veithzal \& Sagala, Ella Jauvani. 2011. Manajemen Sumber Daya Manusia Untuk Perusahaan. Jakarta: PT. Raja GrafindoPersada.

Robbins. 2007. Organizational Behavior. 11 ThE dition. Edisi Bahasa Indonesia: PT. Indeks. - Judge. 2008. Prilaku Organisasi. Edisi Kedua belas. Salemba Empat: Jakarta.

Sugiyono. 2009. Metode Penelitian Kuantitatif Dan $R \& D$. Bandung: Alfabeta.

Rachid Zeffane, Syed A Tipu, James C Ryan. 2011 (http://repository.unej.ac.id/han dle/123456789/57074, diakses 24 Maret 2016)

Sulistyawati Dyah, 2008, Analisis Pengaruh Komitmen Organisasi terhadap Keinginan Berpindah pada Dosen Tetap Fakultas Ekonomi UNTAR di Jakarta, Jurnal Manajemen tahun XII, No.1, Februari 2008 hal.42-56. (www.jurnal.pdii.lipi.go.id/ad min/jurnal/121084256.pdf, Diaksestanggal 17 Maret 2016). 
Wijaya. 2010. "Is Job Insecurity Changing The Psychological Contract",Personnel Review, Vol.29, No.6.

www.Jurnal"Pengaruh_Komitmen_ Organisasi_Dan_Job_Insecurti ty_TerhadapIntensi_Turnover" _(Online)_(Http://www.Daman diri.OrId//File/Luvi_kurnia_sar i_bab_2 .Pdf , Diakses 26 Maret 2016 